\title{
Analisis kemiripan komunitas artropoda predator hama padi penghuni permukaan tanah sawah rawa lebak dengan lahan pinggir di sekitarnya
}

\author{
Similarity analysis of predatory arthropods inhabiting the surface area \\ of swampy rice field and its surrounding
}

\author{
Effendy $^{1 *}$, Usna Hety ${ }^{2}$, Siti Herlinda ${ }^{1}$, Chandra Irsan ${ }^{1}$, Rosdah Thalib $^{1}$ \\ ${ }^{1}$ Jurusan Hama Penyakit Tanaman, Fakultas Pertanian, Universitas Sriwijaya \\ Jalan Raya Palembang Prabumulih, Km 32, Inderalaya, Ogan Ilir 30662 \\ ${ }^{2}$ Balai Karantina Pertanian Kelas I Palembang \\ Jalan Kol. H. Burlian No. 78, Palembang \\ (diterima Januari 2013, disetujui Juli 2013)
}

\begin{abstract}
ABSTRAK
Di Sumatera Selatan luas lahan rawa lebak 1,4 juta ha, 12\% dimanfaatkan sebagai sawah dan perkebunan, sisanya belum dikelola. Penelitian ini bertujuan mengetahui kemiripan komunitas artropoda predator penghuni permukaan tanah sawah rawa lebak dengan lahan pinggir yang berada di sekitarnya. Penelitian dilakukan di Kabupaten Ogan Ilir, Kabupaten Musi Banyuasin, dan Kota Palembang, Sumatera Selatan. Di setiap lokasi dipilih empat tipe habitat rawa lebak, berupa pertanaman padi, semak-semak, padang ilalang, dan hamparan gulma berdaun lebar. Pengambilan sampel artropoda predator penghuni tanah menggunakan perangkap sumuran. Pemasangan perangkap dilakukan sebanyak lima kali, yaitu 15 hari sebelum padi ditanam, saat tanaman padi berumur 1, 2, dan 3 bulan, serta 15 hari setelah panen. Hasil penelitian menunjukkan kelimpahan relatif artropoda predator di permukaan tanah di pertanaman padi adalah $95,03 \%$ dan di habitat lahan pinggir disekitar pertanaman padi adalah $95,12-97,21 \%$. Keanekaragaman spesies artropoda predator di permukaan tanah pada habitat padi dengan habitat lahan pingir menunjukkan tingkat kemiripan $0,73-0,84$. Habitat lahan pinggir di sekitar pertanaman padi dapat menjadi penampung artropoda predator dan sumber musuh alami hama tanaman padi pada musim tanam padi berikutnya
\end{abstract}

Kata kunci: padi, lahan persawahan, pengendalian hayati

\begin{abstract}
There are approximately 1.4 million hectares of swampy area in South Sumatera, but only $12 \%$ of those are being used as farm and plantation. The purpose of this research was to investigate the similarity of arthropod community inhabiting swampy rice field and its surrounding area. This research was conducted in South Sumatera Province covering regency of Musi Banyuasin and Palembang. Four types of swampy area were selected from each location, i.e. rice field, thicket, bush, and swampy land inhabited by broad-leaf weeds. Pitfall trap used to collect arthropod and it installed at five different times. i.e. 15 days before rice planting, one month, two months, and three months after planting, and 15 days after harvest time. The result showed that relative abundance of predatory arthropod dwelling soil in rice field was $95.03 \%$, and habitat surrounding rice field was $95.12-97.21 \%$. The level of similarity of arthropod species between rice field ecosystem and
\end{abstract}

\footnotetext{
*Penulis korespondensi: Effendy. Jurusan Hama Penyakit Tumbuhan, Fakultas Pertanian, Universitas Sriwijaya, Jalan Raya Palembang Prabumulih, Km 32, Inderalaya, Ogan Ilir 30662

Tel: +6281367737715, Email: ta.effendy@yahoo.com
} 
its surrounding area ranged from 0.73 to 0.84 . Thus, the surrounding area of rice field probably can be used as catchment area of predatory arthropod and other pests during planting season.

Key words: rice, rice field, biological control

\section{PENDAHULUAN}

Luas lahan rawa lebak di Sumatera Selatan ada sekitar 1,4 juta ha, 12\% dimanfaatkan sebagai lahan pertanian, berupa sawah, lahan perkebunan, dan sisanya masih belum dikelola (BPS 2007). Di ekosistem sawah rawa lebak Sumatera Selatan belum pernah dilaporkan terjadinya peledakan populasi hama padi. Diduga hal itu ada kaitannya dengan budi daya tanaman padi di sawah rawa lebak Sumatera Selatan yang tidak mengaplikasikan pestisida.

Tumbuhan liar berupa tumbuhan semak semusim yang berdaun lebar dan rumput-rumputan banyak ditemukan pada lahan pinggir di sekitar sawah rawa lebak di Sumatera Selatan. Menurut Herlinda (2007), tumbuhan liar atau semak-semak di lahan pinggir dapat berfungsi sebagai reservoir musuh alami terutama predator dan parasitoid.

Di ekosistem persawahan, artropoda predator merupakan musuh alami yang paling berperan dalam menekan populasi hama di tanaman padi. Menurut Wiedenmann \& Smith (1997), Wissinger (1997), Herlinda \& Effendy (2003), artropoda predator mempunyai kemampuan untuk menyesuaikan diri di ekosistem efemeral. Lahan pinggir di sekitar pertanaman padi dapat berfungsi sebagai tempatberlindung dan sumber musuh alami pertanaman padi pada musim berikutnya.Dengan demikian, musuh alami pada ekosistem tersebut tetap eksis dan berperan dalam menekan populasi hama padi. Lahan pinggir di sekitar pertanaman padi dapat menyediakan mangsa atau inang bagi musuh alami. Lahan pingir juga menyediakan sumber pakan bagi imago serangga predator atau parasitoid, seperti nektar embun madu dan serbuk sari, tempat berlindung (refuges), dan sebagai jembatan musuh alami yang menghubungkan antara dua musim tanam padi (Herlinda 2007).

Habitat musuh alami hama padi tidak hanya pertanaman padi, tetapi juga tumbuhan liar yang tumbuh di pinggir atau sekitar pertanaman padi. Apabila pertanaman padi tidak ada atau kondisi lingkungan tidak sesuai bagi musuh alami, seperti adanya aplikasi pestisida maka vegetasi liar di sekitar pertanaman padi dapat menjadi penampung (sinks) musuh alami yang berasal dari pertanaman padi. Pada musim tanaman padi berikutnya vegetasi itu dapat menjadi sumber (sources) musuh alami.

Penelitian ini bertujuan untuk mengetahui kemiripan komunitas artropoda predator penghuni permukaan tanah sawah rawa lebak dengan lahan pinggir yang ada di sekitarnya. Kemiripan yang tinggi menunjukkan bahwa lahan pinggir dapat berfungsi sebagai tempat berlindung dan jembatan musuh alami pada musim tanam berikutnya.

\section{BAHAN DAN METODE}

\section{Tempat dan waktu}

Penelitian dilakukan di sentra sawah rawa lebak Sumatera Selatan, yaitu di wilayah Pemulutan (Kabupaten Ogan Ilir), Ipil dan Karang Anyar (Kabupaten Musi Banyuasin), serta Gandus (Kota Palembang). Setiap lokasi tersebut dipilih empat tipe habitat rawa lebak, yaitu pertanaman padi, semak-semak, padang ilalang, dan hamparan gulma berdaun lebar. Penelitian dilaksanakan dari bulan Mei 2009 sampai Januari 2010. Pengambilan sampel artropoda predator pada permukaan tanah dilakukan 15 hari sebelum padi ditanam, saat tanaman padi berumur 1, 2, dan 3 bulan, serta 15 hari setelah panen.

\section{Model dan rancangan penelitian}

Penelitian ini merupakan penelitian survei yang datanya dikumpulkan dengan metode observasi (pengamatan). Sampling artropoda predator dilakukan secara disengaja (purposive sampling) pada permukaan tanah rawa lebak yang merupakan habitat artropoda predator tersebut.

\section{Penentuan lokasi penelitian}

Penentuan lokasi berdasarkan luas wilayah yang mempunyai lahan rawa lebak minimal 
100 ha. Lokasi penelitian terletak di tiga daerah tingkat II, yaitu Kabupaten Ogan Ilir, Kabupaten Musi Banyuasin, dan Kota Palembang. Di tiap lokasi penelitian dipilih desa yang mempunyai lahan sawah lebak terluas, yaitu Desa Pemulutan, Ipil, Karang Anyar, dan Gandus.

\section{Pengambilan contoh atropoda penghuni permukaan tanah}

Pengambilan contoh artropoda predator penghuni permukaan tanah menggunakan perangkap sumuran (pitfall trap) sesuai metode Niemela et al. (1990). Perangkap sumuran yang terbuat dari gelas plastik bervolume $250 \mathrm{ml}$. Gelas tersebut diisi dengan larutan formalin 4\% sebanyak $70 \mathrm{ml}$ diletakkan di permukaan tanah di pematang sawah. Di setiap lokasi penelitian dipasang empat perangkap sumuran yang diletakkan di masingmasing sudut petakan. Perangkap dipasang selama 1x24 jam mulai pukul 07:00 WIB, lalu gelas diangkat dan ditutup dengan kantong plastik yang telah dipasang label yang berisi tanggal dan lokasi sampling dan selanjutnya dibawa ke laboratorium.

Artropoda yang tertangkap disortasi, disaring dengan kertas saring, dibilas dengan air steril, lalu dimasukkan dalam wadah yang berisi alkohol $70 \%$. Artropoda yang terkoleksi selanjutnya diidentifikasi dan dihitung jumlah individunya di Laboratorium Entomologi, Jurusan Hama Penyakit Tumbuhan, Fakultas Pertanian, Universitas Sriwijaya. Identifikasi spesies serangga dan labalaba dilakukan berdasarkan pada ciri morfologinya. Identifikasi serangga menggunakan acuan buku Barrion \& Litsinger (1994). Identifikasi laba-laba menggunakan acuan buku Barrion \& Litsinger (1995).

\section{Analisis data}

Untuk membandingkan kemiripan habitat artropoda predator antar habitat yang berbeda digunakan Indeks Sorensen sesuai prosedur Ludwig \& Reynolds (1988) dan Analisis Korespondensi sesuai prosedur Siswadi \& Suharjo (1997). Data komposisi spesies dan jumlah individu artropoda predator digunakan untuk menganalisis kelimpahan dan keanekaragaman spesies artropoda predator. Ukuran keanekaragaman yang digunakan adalah nilai indeks keanekaragaman spesies Shannon, indeks Dominasi Spesies Berger-Parker dan indeks kemerataan spesies dari Pielou (Magurran 1987).

\section{HASIL}

\section{Kelimpahan relatif menurut fungsi ekologi}

Hasil pengamatan menunjukkan bahwa artropoda predator di habitat padi, semak-semak, ilalang, dan gulma berdaun lebar di wilayah Pemulutan, Gandus, Karang Anyar, dan Rantau Panjang lebih tinggi daripada artropoda fungsional lainnya. Kelimpahan artropoda predator pada setiap lokasi pengamatan cukup tinggi dan spesiesnya hampir sama. Kelimpahan artropoda predator di pertanaman padi rata-rata 95,03\%, sedangkan kelimpahan artropoda predator pada habitat di lahan pinggir disekitarnya rata-rata 95,12-97,21\%, sisanya sekitar 5\% merupakan artropoda fungsional lainnya, seperti serangga fitofag dan serangga pengurai (Tabel 1).

\section{Kelimpahan relatif menurut spesies}

Tingginya jumlah spesies artropoda predator yang ditemukan pada permukaan tanah di setiap habitat relatif beragam walaupun perbedaannya sedikit. Jumlah spesies yang paling beragam ditemukan di habitat pertanaman padi ratarata berjumlah 20,75 spesies dan pada habitat lahan pinggir di sekitarnya hanya 14,75-18,25 spesies. Kelimpahan individu artropoda predator di permukaan tanah pada habitat padi rata-rata 205,5 individu dan kelimpahan spesies artropoda predator di permukaan tanah pada habitat lahan pinggir disekitarnya 199,75-241,75 individu (Tabel 2).

Kelimpahan spesies di wilayah Pemulutan, Gandus, Karang Anyar, Rantau Panjang, dan habitat tanaman padi, semak-semak, padang ilalang, dan hamparan gulma berdaun lebar (Gambar 1A). Kelimpahan individu juga dipengaruhi oleh kompleksitas struktur habitat, luas areal habitat, dan iklim mikro di habitat tersebut. Kelimpahan individu di habitat tanaman padi, semak,semak, padang ilalang, dan gulma berdaun lebar di wilayah Pemulutan, Gandus, Karang Anyar, Rantau Panjang dapat dilihat di Gambar 1B.

Kelimpahan spesies predator di wilayah Pemulutan, Gandus, Karang Anyar, Rantau Panjang, pada ekositem tanaman padi didominasi oleh serangga predator Tetraponera laeviceps (Smith.) dan Metioche vittaticolus (Stal.), sedangkan habitat di semak-semak oleh $M$. 
Tabel 1. Kelimpahan relatif (\%) artropoda penghuni permukaan tanah di tanaman padi, semak, ilalang, dan gulma berdaun lebar di Pemulutan, Gandus, Karang Anyar, dan Rantau Panjang

\begin{tabular}{llrrrr}
\hline \multirow{2}{*}{ Wilayah } & \multicolumn{5}{c}{ Kelimpahan Relatif (\%) } \\
\cline { 2 - 6 } Pemulutan & Artropoda & Padi & Semak & \multicolumn{1}{c}{ Ilalang } & Gulma berdaun lebar \\
& & $\mathrm{n}=291$ & $\mathrm{n}=309$ & $\mathrm{n}=318$ & $\mathrm{n}=214$ \\
& Predator & 93,47 & 97,74 & 98,11 & 97,66 \\
& Fitofag & 4,12 & 1,94 & 1,89 & 2,34 \\
& Lain-lain & 2,41 & 0,32 & 0,00 & 0,00 \\
\hline \multirow{2}{*}{ Gandus } & & $\mathrm{n}=311$ & $\mathrm{n}=380$ & $\mathrm{n}=173$ & $\mathrm{n}=132$ \\
& Predator & 95,82 & 97,63 & 92,49 & 97,78 \\
& Fitofag & 1,93 & 2,37 & 4,05 & 2,22 \\
& Lain-lain & 2,25 & 0,00 & 3,47 & 0,00 \\
\hline Karang Anyar & & $\mathrm{n}=124$ & $\mathrm{n}=173$ & $\mathrm{n}=288$ & $\mathrm{n}=255$ \\
& Predator & 96,77 & 90,23 & 95,83 & 98,04 \\
& Fitofag & 2,42 & 6,32 & 4,17 & 1,57 \\
& Lain-lain & 0,81 & 3,45 & 0,00 & 0,39 \\
\hline \multirow{2}{*}{ Ratau Panjang } & & $\mathrm{n}=168$ & $\mathrm{n}=143$ & $\mathrm{n}=134$ & $\mathrm{n}=172$ \\
& Predator & 94,05 & 96,50 & 94,03 & 95,35 \\
& Fitofag & 4,76 & 3,50 & 5,97 & 4,65 \\
& Lain-lain & 1,19 & 0,00 & 0,00 & 0,00 \\
\hline Total & & $\mathrm{n}=894$ & $\mathrm{n}=1005$ & $\mathrm{n}=913$ & $\mathrm{n}=743$ \\
& Predator & 380,11 & 382,10 & 380,46 & 388,83 \\
& Fitofag & 13,23 & 14,13 & 16,08 & 2,73 \\
& Lain-lain & 6,66 & 3,77 & 3,47 & 10,78 \\
\hline Rerata & & $\mathrm{n}=223,5$ & $\mathrm{n}=251,25$ & $\mathrm{n}=228,25$ & $\mathrm{n}=185,75$ \\
& Predator & 95,03 & 95,51 & 95,12 & 97,21 \\
& Fitofag & 3,31 & 3,53 & 4,02 & 0,69 \\
& Lain-lain & 1,67 & 0,94 & 0,87 & 2,69 \\
\hline
\end{tabular}

vittaticolus, di habitat padang ilalang oleh Oecopholla smaragdina (Fabr.) dan M. vittaticolus, dan di habitat gulma berdaun lebar oleh Notoncus ectatommoides (Forrel) dan M. vittaticolus. Artropoda predator yang dominan di ekositem tanaman padi, padang ilalang dan gulma berdaun ialah Pardosa pseudoannulata (Boes.\&Str.), dan di habitat semak-semak didominasi oleh Erygone bifurca (Lock.) (Tabel 3).

\section{Karakteristik komunitas artropoda predator}

Jumlah spesimen dan jumlah spesies yang ditemukan di masing-masing lokasi penelitian dan habitat sangat bervariasi. Jumlah spesimen yang ditemukan tidak terkait langsung dengan jumlah spesies yang ada di suatu habitat.

Hasil pengamatan secara langsung menunjukkan bahwa habitat padi merupakan hamparan sawah lebak yang luas dibandingkan dengan lahan pinggir di sekitarnya. Luasnya hamparan habitat menjadi penyebab melimpahnya jumlah spesies yang ditemukan. Indeks keanekaragaman spesies artropoda predator di habitat tanaman padi lebih tinggi daripada di ekosisitem lain dengan nilai indeks mencapai 1,08 dan di habitat lahan pinggir nilai indeksnya berkisar antara 0,98-1,04. Nilai indeks dominasi artropoda predator di tanaman padi 0,22 . Nilai tersebut lebih rendah dibandingkan dengan nilai indeks dominasi artropoda predator di lahan pinggir yang berkisar antara 0,27-33. Indeks kemerataan spesies pada pertanaman padi dan di lahan pinggir hampir sama dengan nilai 0,36 dan 0,35-0,37 (Tabel 2). Indeks Berger Parker artropoda predator di permukaan tanah pada habitat padi rata-rata 0,22 dan di habitat lahan pinggir di sekitaranya berkisar antara 0,27-0,37. Indeks Pielou artropoda predator di permukaan tanah di habitat padi rata-rata 0,36 dan di habitat lahan pinggir di sekitarnya berkisar antara 0,35-0,37 (Tabel 2).

\section{Kemiripan komunitas artropoda predator di lahan pinggir dengan pertanaman padi}

Hasil analisis kemiripan artropoda predator di tanaman padi dengan habitat yang berada di sekitarnya berupa semak-semak, padang ilalang, 
Tabel 2. Karakteristik komunitas artropoda predator penghuni permukaan tanah di tanaman padi, semak, ilalang dan gulma berdaun lebar

\begin{tabular}{|c|c|c|c|c|}
\hline Karakteristik komunitas & Padi & Semak & Ilalang & $\begin{array}{c}\text { Gulma berdaun } \\
\text { lebar }\end{array}$ \\
\hline \multicolumn{5}{|l|}{ Pemulutan: } \\
\hline Jumlah spesimen/kelimpahan (individu) & 272,00 & 302,00 & 312,00 & 209,00 \\
\hline Jumlah spesies & 28,00 & 20,00 & 26,00 & 17,00 \\
\hline Indeks keanekaragaman spesies (Indeks Shannon) & 1,22 & 1,17 & 1,18 & 1,10 \\
\hline Indeks dominasi spesies (Indeks Berger Parker) & 0,16 & 0,12 & 0,13 & 0,15 \\
\hline Indeks kemerataan spesies (Indeks Pielou) & 0,37 & 0,39 & 0,36 & 0,39 \\
\hline \multicolumn{5}{|l|}{ Gandus: } \\
\hline Jumlah spesimen/kelimpahan (individu) & 272,00 & 370,00 & 159,00 & 176,00 \\
\hline Jumlah spesies & 20,00 & 17,00 & 17,00 & 14,00 \\
\hline Indeks keanekaragaman spesies (Indeks Shannon) & 1,04 & 0,99 & 0,92 & 0,99 \\
\hline Indeks dominasi spesies (Indeks Berger Parker) & 0,27 & 0,34 & 0,38 & 0,26 \\
\hline Indeks kemerataan spesies (Indeks Pielou) & 0,35 & 0,35 & 0,33 & 0,38 \\
\hline \multicolumn{5}{|l|}{ Karang Anyar: } \\
\hline Jumlah spesimen/kelimpahan (individu) & 120,00 & 157,00 & 277,00 & 250,00 \\
\hline Jumlah spesies & 18,00 & 18,00 & 16,00 & 15,00 \\
\hline Indeks keanekaragaman spesies (Indeks Shannon) & 1,06 & 0,96 & 0,90 & 0,90 \\
\hline Indeks dominasi spesies (Indeks Berger Parker) & 0,22 & 0,30 & 0,40 & 0,37 \\
\hline Indeks kemerataan spesies (Indeks Pielou) & 0,37 & 0,37 & 0,32 & 0,33 \\
\hline \multicolumn{5}{|l|}{ Rantau Panjang } \\
\hline Jumlah spesimen/kelimpahan (individu) & 158,00 & 138,00 & 146,00 & 164,00 \\
\hline Jumlah spesies & 17,00 & 16,00 & 14,00 & 13,00 \\
\hline Indeks keanekaragaman spesies (Indeks Shannon) & 1,00 & 1,04 & 1,00 & 0,93 \\
\hline Indeks dominasi spesies (Indeks Berger Parker) & 0,22 & 0,30 & 0,40 & 0,37 \\
\hline Indeks kemerataan spesies (Indeks Pielou) & 0,35 & 0,37 & 0,38 & 0,36 \\
\hline \multicolumn{5}{|l|}{ Total } \\
\hline Jumlah spesimen/kelimpahan (individu) & 822,00 & 967,00 & 894,00 & 799,00 \\
\hline Jumlah spesies & 85,00 & 71,00 & 73,00 & 59,00 \\
\hline Indeks keanekaragaman spesies (Indeks Shannon) & 4,32 & 4,16 & 4,00 & 3,92 \\
\hline Indeks dominasi spesies (Indeks Berger Parker) & 0,87 & 1,06 & 1,31 & 1,15 \\
\hline Indeks kemerataan spesies (Indeks Pielou) & 1,44 & 1,48 & 1,39 & 1,46 \\
\hline \multicolumn{5}{|l|}{ Rerata } \\
\hline Jumlah spesimen/kelimpahan (individu) & 205,50 & 241,75 & 223,5 & 199,75 \\
\hline Jumlah spesies & 20,75 & 17,75 & 18,25 & 14,75 \\
\hline Indeks keanekaragaman spesies (Indeks Shannon) & 1,08 & 1,04 & 1,00 & 0,98 \\
\hline Indeks dominasi spesies (Indeks Berger Parker) & 0,22 & 0,27 & 0,33 & 0,29 \\
\hline Indeks kemerataan spesies (Indeks Pielou) & 0,36 & 0,37 & 0,35 & 0,37 \\
\hline
\end{tabular}

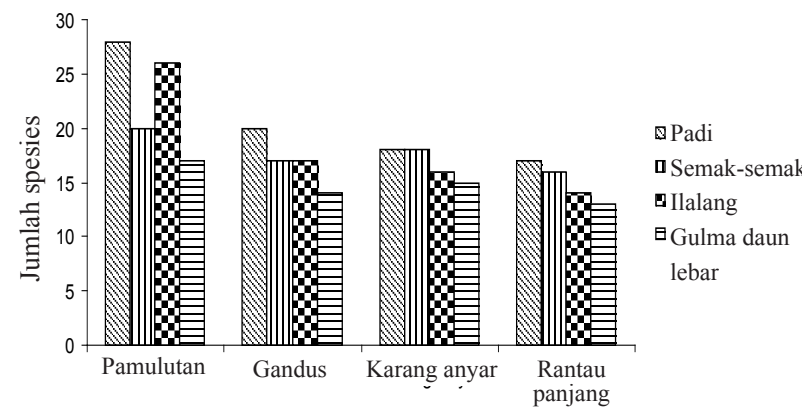

A

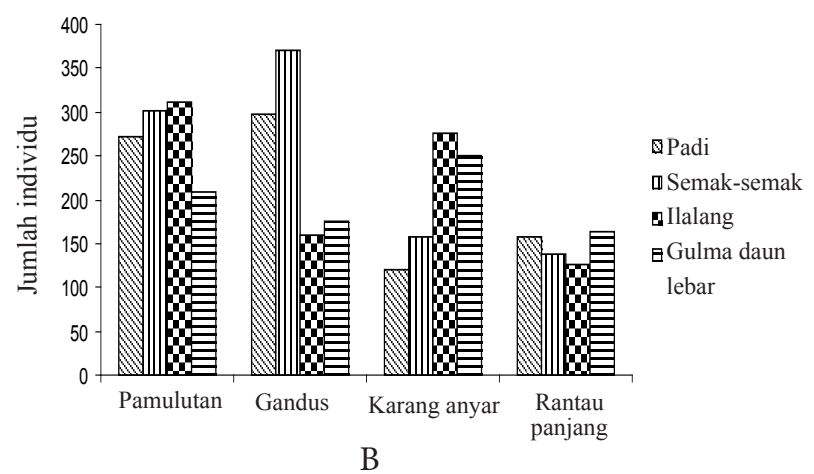

B

Gambar 1. Artropoda predator penghuni permukaan tanah yang ditemukan pada empat desa, A: kekayaan spesies; B: kelimpahan individu. 
Tabel 3. Kelimpahan spesies artropoda predator penghuni permukaan tanah pada tanaman padi, semak, ilalang, dan gulma berdaun lebar di Pemulutan, Gandus, Karang Anyar, dan Rantau Panjang

\begin{tabular}{|c|c|c|c|c|c|}
\hline \multirow[b]{2}{*}{ Famili } & \multirow[b]{2}{*}{ Spesies } & \multicolumn{4}{|c|}{ Kelimpahan (individu) } \\
\hline & & Padi & Semak & Ilalang & $\begin{array}{c}\text { Gulma daun } \\
\text { lebar }\end{array}$ \\
\hline \multicolumn{6}{|l|}{ Insecta } \\
\hline Belostomatidae & Lethocerus insulanus (Mont.) & 0 & 0 & 1 & 0 \\
\hline \multirow[t]{9}{*}{ Carabidae } & Amara aena & 1 & 2 & 0 & 0 \\
\hline & Amara chalcites (Dejean) & 6 & 2 & 2 & 0 \\
\hline & Calathus melanocephalus & 3 & 0 & 0 & 0 \\
\hline & Chlaenius circumodatus (Dej.) & 2 & 0 & 1 & 0 \\
\hline & Pherosophus occipitaliis (Mc.) & 48 & 7 & 23 & 1 \\
\hline & Pherosophus javanus (Dej.) & 6 & 3 & 0 & 0 \\
\hline & Pterostichus cupreus & 0 & 0 & 1 & 0 \\
\hline & Pterostichus strenuus & 10 & 2 & 4 & 0 \\
\hline & Pterostichus versicolor & 0 & 0 & 0 & 1 \\
\hline \multirow[t]{8}{*}{ Formicidae } & Scarites terricola & 0 & 0 & 1 & 0 \\
\hline & Diacamma austral (Fabr.) & 28 & 57 & 14 & 39 \\
\hline & Dolichoderus scabridus (Roger.) & 1 & 8 & 4 & 8 \\
\hline & Myrmacia nigriceps (Mayr.) & 6 & 6 & 11 & 31 \\
\hline & Notoncus ectatommoides (Forrel) & 16 & 50 & 38 & 73 \\
\hline & Oecopholla smaragdina (Fabr.) & 46 & 41 & 71 & 31 \\
\hline & Pheidole sp & 51 & 18 & 27 & 36 \\
\hline & Tetraponera laeviceps (Smith.) & 72 & 38 & 38 & 49 \\
\hline Gryllidae & Metioche vittaticolus (Stal.) & 71 & 93 & 77 & 73 \\
\hline Hydraenidae & Hydraena luridipennis & 2 & 2 & 1 & 0 \\
\hline Hydrophilidae & Hydrocanthus australiae (Whnke.) & 1 & 0 & 0 & 0 \\
\hline Labiduridae & Labidura truncate (Kirby.) & 4 & 0 & 0 & 2 \\
\hline Lathridiidae & Corticaria pubescens & 3 & 0 & 0 & 0 \\
\hline Myrmecophilidae & Myrmecophillus testaceus (Hend) & 35 & 53 & 33 & 40 \\
\hline Napidae & Ranatra dispar (Mont.) & 0 & 1 & 0 & 0 \\
\hline Phalacridae & Stilbus testaceus & 25 & 0 & 0 & 0 \\
\hline \multirow[t]{2}{*}{ Staphylinidae } & Carpelimus alangatus & 0 & 0 & 1 & 0 \\
\hline & Paederus riparius & 1 & 0 & 0 & 0 \\
\hline \multicolumn{6}{|l|}{ Arachnida } \\
\hline \multirow[t]{2}{*}{ Araneidae } & Cyclosa mulmeinensis (Thorell.) & 37 & 47 & 2 & 0 \\
\hline & Neoscona theisis & 0 & 0 & 1 & 0 \\
\hline \multirow[t]{4}{*}{ Linyphiidae } & Atypena adelinae n.sp. & 16 & 36 & 21 & 12 \\
\hline & Atypena thailanica n.sp. & 0 & 48 & 21 & 2 \\
\hline & Bathyphantes tegalongensis $\mathrm{n} . \mathrm{sp}$ & 4 & 6 & 2 & 0 \\
\hline & Erygone bifurca (Lock.) & 42 & 71 & 42 & 42 \\
\hline \multirow[t]{8}{*}{ Lycosidae } & Arctosa tanakai n.sp. & 4 & 1 & 0 & 4 \\
\hline & Pardosa birmanica Sim. & 31 & 52 & 40 & 35 \\
\hline & Pardosa iriensis n.sp & 9 & 12 & 6 & 9 \\
\hline & Pardosa pseudoannulata (Boes.\&Str.) & 71 & 7 & 76 & 68 \\
\hline & Pardosa sumatrana (Thorell.) & 37 & 34 & 34 & 24 \\
\hline & Pardosa warayensis $\mathrm{n} . \mathrm{sp}$. & 0 & 2 & 3 & 0 \\
\hline & Pirata luzonensis $\mathrm{n} . \mathrm{sp}$. & 0 & 1 & 0 & 0 \\
\hline & Trochosa canopii n.sp. & 5 & 0 & 8 & 0 \\
\hline \multirow[t]{3}{*}{ Salticidae } & Hasarius adansoni & 0 & 0 & 1 & 0 \\
\hline & Plexippus petersi (Karsch.) & 0 & 1 & 0 & 1 \\
\hline & Plexippus paykulii (Audo.) & 0 & 1 & 0 & 0 \\
\hline Theriidae & Theridium $\mathrm{sp}$ & 1 & 0 & 0 & 0 \\
\hline Thomisiidae & Xysticus palawanicus n.sp. & 1 & 1 & 0 & 0 \\
\hline Jumlah spesies & & 34 & 31 & 31 & 21 \\
\hline
\end{tabular}


dan hamparan gulma berdaun lebar menunjukkan kemiripan yang tinggi. Indeks Sorensen yang menunjukkan kemiripan habitat tanaman padi dengan padang ilalang nilainya 0,73 . Nilai kemiripan tanaman padi dengan semak-semak dan hamparan gulma berdaun lebar sangat mirip dengan Indek Sorensen rata-rata 0,79-0,84 (Tabel 4).

\section{PEMBAHASAN}

Kelimpahan relatif artropoda predator di pertanaman padi $95,03 \%$ hampir sama dengan kelimpahan relatif artropoda predator di habitat di lahan pinggir di sekitar pertanaman padi 95,1297,21\%. Hal itu menunjukkan bahwa pertanaman padi dan lahan pinggir yang berada di sekitarnya mempunyai hubungan yang erat. Artinya, lahan yang berada di sekitar pertanaman padi dapat menjadi jembatan artropoda predator antara pertanaman padi pada musim berikutnya. Selain itu, lahan pinggir di sekitar pertanaman padi dapat berfungsi sebagai tempat berlindung dan sumber musuh alami bagi pertanaman padi pada musim berikutnya. Dengan demikian, musuh alami di habitat tersebut tetap eksis dan dapat berperan dalam menekan populasi hama padi. Keadaan tersebut dapat disebabkan oleh kebiasaan petani di lahan rawa lebak yang dalam bercocok tanam padi tidak melakukan pengolahan tanah, pemupukan, dan penggunaan pestisida.

Apabila petani menggunakan pestisida sentetis akan menyebabkan populasi artropoda predator menjadi rendah. Bulduck et al. (2005) melaporkan bahwa toksisitas insektisida dapat mengurangi aktivitas artropoda predator yang selanjutnya dapat mempengaruhi kelimpahan populasi predator.

Tabel 4. Matriks kemiripan (Indeks Sorensen) komunitas artropoda predator penghuni permukaan tanah di Pemulutan, Gandus, Karang Anyar, dan Rantau Panjang

\begin{tabular}{|c|c|c|c|c|c|}
\hline Wilayah & Habitat & Padi & Semak & Ilalang & $\begin{array}{c}\text { Gulma berdaun } \\
\text { lebar }\end{array}$ \\
\hline \multicolumn{6}{|l|}{ Pemulutan } \\
\hline & Padi & 1,00 & & & \\
\hline & Ilalang & 0,70 & 1,00 & & \\
\hline & Semak & 0,67 & 0,74 & 1,00 & \\
\hline & Gulma berdaun lebar & 0,84 & 0,65 & 0,76 & 1,00 \\
\hline \multicolumn{6}{|l|}{ Gandus } \\
\hline & Padi & 1,00 & & & \\
\hline & Ilalang & 0,71 & 1,00 & & \\
\hline & Semak & 0,82 & 0,67 & 1,00 & \\
\hline & Gulma berdaun lebar & 0,69 & 0,73 & 0,80 & 1,00 \\
\hline \multicolumn{6}{|l|}{ Karang Anyar } \\
\hline & Padi & 1,00 & & & \\
\hline & Ilalang & 0,69 & 1,00 & & \\
\hline & Semak & 0,82 & 0,90 & 1,00 & \\
\hline & Gulma berdaun lebar & 0,68 & 0,84 & 0,97 & 1,00 \\
\hline \multicolumn{6}{|l|}{ Rantau Panjang } \\
\hline & Padi & 1,00 & & & \\
\hline & Ilalang & 0,80 & 1,00 & & \\
\hline & Semak & 0,86 & 0,86 & 1,00 & \\
\hline & Gulma berdaun lebar & 0,83 & 0,88 & 0,81 & 1,00 \\
\hline \multicolumn{6}{|l|}{ Total } \\
\hline & Padi & 1,00 & & & \\
\hline & Ilalang & 2,90 & 1,00 & & \\
\hline & Semak & 3,17 & 3,17 & 1,00 & \\
\hline & Gulma berdaun lebar & 3,04 & 3,10 & 3,34 & 1,00 \\
\hline \multicolumn{6}{|l|}{ Rerata } \\
\hline & Padi & 1,00 & & & \\
\hline & Ilalang & 0,73 & 1,00 & & \\
\hline & Semak & 0,79 & 0,79 & 1,00 & \\
\hline & Gulma berdaun lebar & 0,76 & 0,78 & 0,84 & 1,00 \\
\hline
\end{tabular}


Pestisida bukan saja mempengaruhi aktifitas artropoda predator, tetapi dapat membunuh artropoda berguna lainya. Kelimpahan populasi artropoda predator pada permukaan tanah erat kaitannya dengan ekosistem pertanaman padi dan vegetasi yang tumbuh di lahan tersebut. Lahan pinggir tersebut dapat menyediakan mangsa atau inang, sumber pakan, tempat berlindung, penampung, dan menjadi sumber musuh alami pada musim berikutnya (Herlinda 2007; Herlinda et al. 2000).

Kelimpahan populasi artropoda predator pada tanaman padi dan lahan pinggir yang berada di sekitarnya, menunjukkan bahwa artropoda predator tersebut telah beradaptasi pada habitat tanaman padi. Habitat pinggir (edge habitat) yang terdiri atas rerumputan dan semak-semak di ekosistem sawah yang polikultur dapat mempengaruhi keberadaan laba-laba di ekosistem tersebut (Suana \& Haryanto 2007). Vegetasi yang tumbuh di lahan pinggir dapat berfungsi sebagai penampung artropoda predator dan dapat menyediakan relung yang sesuai bagi kehidupannya. Dengan demikian, mempertahankan vegetasi yang tumbuh di lahan pinggir berupa semak-semak, padang ilalang (rerumputan) dan gulma berdaun lebar dapat menguntungkan dalam pelestarian artropoda predator.

Jumlah spesies yang ditemukan di habitat pertanaman padi lebih beragam daripada di lahan pingir yang berada di sekitarnya. Pertanaman padi merupakan tempat hidup mangsa yang cocok karena tanaman padi dapat menyediakan makanan yang cukup bagi serangga fitofag. Di samping itu, habitat tanaman padi lebih luas daripada habitat yang lain. Hal itu akan menyebabkan kelimpahan artropoda predator tinggi. Sebaliknya, hamparan gulma berdaun lebar bukan merupakan tempat penyedia makanan yang baik bagi serangga fitofag.

Jumlah individu yang tinggi di masing-masing ekosistem dipengaruhi oleh luas hamparan. Hamparan yang luas menjadi tempat persediaan makanan dan tempat berlindung bagi serangga fitofag. Hal itu mengakibatkan jumlah artropoda predator penghuni habitat tersebut juga makin tinggi. Keanekaragaman spesies artropoda predator di suatu habitat dipengaruhi oleh keanekaragaman spesies tumbuhan inang yang menjadi tempat hidup serangga fitofag sebagai mangsa artropoda predator. Struktur vegetasi tumbuhan yang kompleks (polikultur) dapat mendukung kelimpahan spesies artropoda predator daripada struktur vegetasi tumbuhan yang sederhana (Herlinda 2000). Semakin kompleks habitat maka kekayaan spesies artropoda akan semakin tinggi (Valverde \& Lobo 2007). Menurut Marc et al. (1999), keberadaan artropoda predator di suatu habitat dipengaruhi oleh keanekaragaman mangsa dan kompleksitas habitat. Vegetasi yang berada di pinggir persawahan tersebut menyediakan mangsa atau inang bagi musuh alami, sumber pakan, tempat berlindung, penampung, dan menjadi sumber musuh alami pada musim berikutnya.

Indeks keanekaragaman spesies artropoda predator pada habitat tanaman padi lebih tinggi dibandingkan dengan ekosisitem lainya, yaitu 1,08 dan habitat lahan pinggir $0,98-1,04$. Indeks keanekaragaman spesies artropoda predator di habitat tanaman padi tinggi mengakibatkan indeks dominasi artropoda predator di tanaman padi menjadi rendah, yaitu 0,22 . Sebaliknya, indeks dominasi artropoda yang berada di lahan pinggir lebih tinggi, yaitu 0,27-0,33.

Tingginya tingkat dominasi di suatu ekosistem menunjukkan adanya kerapatan yang tinggi pada spesies tertentu dibandingkan dengan spesies yang lain. Hal itu akan berpengaruh terhadap tingkat kemerataan spesies di suatu ekosistem. Tingginya tingkat dominasi dan rendahnya tingkat kemerataan spesies serangga artropoda predator dipengaruhi oleh perbedaan keanekaragaman tipe ekosistem dan perbedaan kompleksitas struktur habitat (Waluyo 2008). Week dan Holitzer (2000) melaporkan bahwa ekosistem sawah yang kompleks menyediakan beragam tipe habitat dan dapat meningkatkan jumlah spesies laba-laba yang berkoeksistensi di dalamnya. Herlinda (2007) melaporkan bahwa vegetasi tumbuhan yang beranekaragam cenderung memiliki spesies fauna yang beranekaragam pula.

Indeks kemerataan spesies artropoda predator di permukaan tanah pada habitat padi rata-rata 0,36, dan indeks kemerataan spesies artropoda predator di permukaan tanah pada habitat yang berada di lahan pinggir di sekitarnya 0,35-0,37. Indeks kemerataan spesies artropoda predator di permukaan tanah pada habitat padi dan pada habitat yang berada di lahan pinggir di sekitarnya 
relatif sama. Keadaan itu menunjukkan bahwa habitat di lahan pinggir dapat bermanfaat untuk konservasi musuh alami sehingga tidak terjadi ledakan populasi hama di tanaman padi. Menurut Herlinda et al. (2000), lahan pinggir yang berada di sekitar pertanaman padi tersebut dapat menjadi sumber musuh alami yang akan datang ke pertanaman padi.

Indek Sorensen pertanaman padi dengan lahan pinggir yang berada di sekitarnya sangat mirip. Dengan demikian, lahan pinggir menyediakan habitat yang sesuai bagi kehidupan artropoda predator hama padi. Lahan pinggir dapat dimanfaatkan sebagai jembatan musuh alami sebelum dan sesudah musim tanam padi. Hal yang sama dilaporkan oleh Suana dan Haryanto (2007) bahwa vegetasi tumbuhan yang tumbuh di sekitar tanaman budi daya sebagai habitat sementara apabila tanaman budi daya tidak tersedia di sawah, lalu melakukan rekolonisasi apabila habitat utamanya telah ada. Sesuai dengan pendapat French et al. (2001), habitat alami dapat menyediakan musuh alami yang melimpah sehingga dapat dimanfaatkan sebagai pengendali hama tanaman.

\section{KESIMPULAN}

Kelimpahan relatif artropoda predator di permukaan tanah pada habitat padi 95,03\% dan kelimpahan relatif artropoda predator di permukaan tanah di habitat lahan pinggir yang berada di sekitarnya 95,12-97,21\%. Kemiripan komunitas (Indeks Sorensen) artropoda predator di permukaan tanah pada habitat padi dengan artropoda predator di permukaan tanah di habitat lahan pinggir yang berada di sekitarnya menunjukkan tingkat kemiripan 0,73-0,84. Habitat lahan pinggir yang berada di sekitar pertanaman padi dapat menjadi penampung artropoda predator dan sumber musuh alami hama tanaman padi pada musim tanam padi berikutnya.

\section{UCAPAN TERIMA KASIH}

Ucapan terimakasih kepada Direktorat Jenderal Pendidikan Tinggi Departemen Pendidikan Nasional yang telah mendanai penelitian ini sesuai dengan Surat Perjanjian Pelaksanaan Hibah 68
Penelitian Nomor: 432/H9/PL/2009. Tanggal 06 April 2009. a.n Effendy. Ucapan terima kasih juga disampaikan kepada semua pihak yang terlibat dalam penelitian ini.

\section{DAFTAR PUSTAKA}

Barrion AT, Litsinger JA. 1994. Taxonomy of rice insect pests and their Arthropod parasites and predators. In: E.A. Heinrichs (Ed.). Biology and Management of Rice Insects. pp. 13-36. New Delhi: Wiley Eastern Limited.

Barrion AT, Litsinger JA. 1995. Riceland Spiders of South and Southeast Asia. Philippines: International Rice Research Institute.

[BPS] Biro Pusat Statistika. 2007. Luas Lahan Menurut Penggunaannya di Sumatera Selatan. Palembang: Biro Pusat Statistika.

Bulduc E, Buddle CM, Bostanian NJ, Vincent C. 2005. Ground-dwelling spider fauna (Araneae) of two vineyard in Southern Quebec. Environmental Entomol 34:635-645. doi: http:// dx.doi.org/10.1603/0046-225X-34.3.635.

French BW, Elliot NC, Berbert RC, Burd JD. 2001. Effect of riparian and grassland habitats on ground beetle (Coleoptera: Carabidae) Assemblages in adjacent wheat fields. Environmental Entomol 2:225-121. doi: http://dx.doi.org/10.1603/0046225X-30.2.225.

Herlinda S. 2000. Analisa Komunitas Artropoda Predator Penghuni Lansekap Persawahan di Daerah Cianjur Jawa Barat. Disertasi. Bogor: Institut Pertanian Bogor.

Herlinda S, Kandowangko DS, Winasa IW, Rauf A. 2000. Fauna artropoda penghuni habitat pinggiran di ekosistem persawahan. Di dalam: Sunaryo E (Ed.), Prosiding Simposium Keanekaragaman Hayati Artropoda pada Sistem Produksi Pertanian (Cipayung, 16-18 Oktober 2000). pp. 163-174. Cipayung: Perhimpunan Entomologi Indonesia dan Yayasan KEHATI.

Herlinda S. 2007. Struktur komunitas dan potensi kumbang predator (Carabidae dan laba-laba) penghuni ekosistem sawah dataran tinggi Sumatera Selatan. Di dalam: Konferensi Nasional Konservasi Serangga 2007, Konservasi Serangga pada Bentang Alam Tropis: Peluang dan Tantangan (Bogor, 27-30 Januari 2007). Tersedia di: http://eprints.unsri.ac.id/248/1/ KOMUNITAS\%20DAN\%20POTENSI\%20 KUMBANG\%20CARABIDAE.pdf [diakses 2 Januari 2013]. 
Herlinda S, Effendy TA. 2003. Jenis Artropoda predator penghuni tajuk dan permukaan tanah di ekosistem tanaman padi, M23.1-7. Di dalam: Prosiding Seminar Lokakarya Nasional Ketahanan Pangan dalam Era Otonomi Daerah dan Globalisasi (Palembang 2-4 Maret 2003). Palembang: Universitas Sriwijaya.

Ludwig JA, Reynolds JF. 1988. Statistical Ecology: A Primer on Methods and Computing. New York: John Wiley \& Sons.

Magurran AE. 1987. Ecological Diversity and Its Measurement. New Jersey: Princeton University Press.

Marc P, Canard A, Ynes F. 1999. Spiders (Araneae) useful for pest limitation and bioindication. Agricultur, Ecosystems and Environment. 74:229-273. doi: http://dx.doi.org/10.1016/ S0167-8809(99)00038-9.

Niemela JN, Halme E, Haila Y. 1990. Balancing sampling effort in pitfall trapping of carabid beetles. Entomologica Fennica 1:233-238.

Siswadi, Suharjo B. 1997. Analisis Eksplorasi Data Peubah Ganda. Bogor: Jurusan Matematika, FMIPA, IPB dan HEDS Project Dikti Depdikbud.

Suana IW, Haryanto H. 2007. Keanekaragaman Laba-Laba pada Ekosistem Sawah Monokultur dan Polikultur di Pulau Lombok. Mataram: Universitas Mataram.

Valverde AJ, Lobo JM. 2007. Determinants of local spider (Araneidae and Thomisiidae) species richnes on a regional scale; climate and altitude vs habitat structure. Ecological Entomology 32:113-122. doi: http://dx.doi.org/10.1111/ j.1365-2311.2006.00848.x.

Waluyo. 2008. Keanekaragaman Spesies dan Kelimpahan Artropoda pada Sawah yang di Aplikasi dan tanpa Aplikasi Insektisida. Tesis. Palembang: Universitas Sriwijaya.

Weeks RD, Holitzer TO. 2000. Habitat and season in structuring ground-dwelling spider (Araneae) communities in a shortgrass steppe ecosytem. Environmental Entomology 6:1164-1172. doi: http://dx.doi.org/10.1603/0046-225X-29.6.1164.

Wiedenmann RN, Smith JW. 1997. Attributes of natural enemies in ephemeral crop habitat. Biological Control 10:16-22. doi: http://dx.doi. org/10.1006/bcon.1997.0544.

Wissinger SA. 1997. Cyclic colonization in predictably ephemeral habitat: A template for biological control in annual crop systems. Biological Control 10:4-15. doi: http://dx.doi. org/10.1006/bcon.1997.0543. 